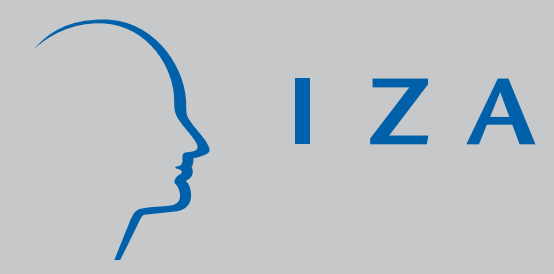

IZA DP No. 1535

The Persistent Segregation of Girls into Lower-Paying J obs while in School

Peter Kooreman

March 2005 


\title{
The Persistent Segregation of Girls into Lower-Paying Jobs while in School
}

\author{
Peter Kooreman \\ University of Groningen \\ and IZA Bonn
}

\section{Discussion Paper No. 1535 \\ March 2005}

\author{
IZA \\ P.O. Box 7240 \\ 53072 Bonn \\ Germany \\ Phone: +49-228-3894-0 \\ Fax: +49-228-3894-180 \\ Email: iza@iza.org
}

\begin{abstract}
Any opinions expressed here are those of the author(s) and not those of the institute. Research disseminated by IZA may include views on policy, but the institute itself takes no institutional policy positions.
\end{abstract}

The Institute for the Study of Labor (IZA) in Bonn is a local and virtual international research center and a place of communication between science, politics and business. IZA is an independent nonprofit company supported by Deutsche Post World Net. The center is associated with the University of Bonn and offers a stimulating research environment through its research networks, research support, and visitors and doctoral programs. IZA engages in (i) original and internationally competitive research in all fields of labor economics, (ii) development of policy concepts, and (iii) dissemination of research results and concepts to the interested public.

IZA Discussion Papers often represent preliminary work and are circulated to encourage discussion. Citation of such a paper should account for its provisional character. A revised version may be available directly from the author. 


\section{ABSTRACT}

\section{The Persistent Segregation of Girls into Lower-Paying Jobs while in School *}

This paper analyzes gender differences in jobs while in high school. The availability of school class based samples with detailed information on teenage jobs allows for a comparison of the behavior of boys and girls who are in the same school class, and thus have virtually identical education levels. Even within these highly homogeneous groups, boys earn substantially more than girls. The earnings gap cannot be explained by differences in participation rates and hours of work, nor by gender wage gaps within job types. It is entirely due to the fact that girls work more in job types with relatively low wages, in particular babysitting. During the period considered, 1984-2001, the gender patterns of jobs while in school largely remained unchanged.

JEL Classification: J16, J22

Keywords: labor market, gender differences, teenage behavior

Corresponding author:

Peter Kooreman

Department of Economics

University of Groningen

P.O.B. 800

9700 AV Groningen

The Netherlands

E-mail: p.kooreman@eco.rug.nl

\footnotetext{
* Discussions with Bert Schoonbeek, Adriaan Soetevent, and participants in the session "Bargaining in Families" at the AEA 2005 Meeting in Philadelphia were very helpful in shaping this paper.
} 


\section{Introduction}

Segregation of women into lower-paying occupations is a primary source of the gender earnings gap; see for example Blau and Kahn (2000, 2003, 2004) and Bayard et al. (2003). The gender earnings gap is an important motivation for the strong commitment of many governments to advancing equal education opportunities for boys and girls, and to equal pay acts and child care policies ${ }^{1}$.

In this paper I provide evidence showing that segregation of women into lowerpaying occupations already occurs at the earliest stage of their labor market careers. I compare jobs while in school of boys and girls aged 17 or 18, using school class based samples covering the period 1984-2001. By controlling for school class specific fixed effects any differences in the labor market behavior of boys and girls are unlikely to be related to unobserved differences in education. Even within these highly homogeneous groups boys earn substantially more than girls. The earnings gap cannot be explained by differences in participation rates or hours of work. It is entirely due to the fact that girls work more in job types with relatively low wages, primarily babysitting.

The gender patterns of jobs while in school largely remained unchanged during the almost two decades considered. In particular, participation rates and hours in babysitting show no systematic change for girls and boys in all academic levels within high school, even though the wage rate of babysitting has decreased relative to the wage rates of other job types.

\section{The NSYS Data}

The empirical analysis is based on the Nationaal Scholierenonderzoek (Dutch National School Youth Survey, NSYS). The NSYS surveys took place in 1984, 1990,

\footnotetext{
${ }^{1}$ In The Netherlands - the country where the present paper's data have been collected - the Lubbers administration widely advertised the slogan "A smart girl is prepared for her future" (riming in Dutch) during the late 1980s and early 1990s. This national campaign focused on girls aged 15 and 16, and encouraged them to pursue higher education and careers in typical male professions.
} 
1992, 1994, 1996, 1999, and 2001. Each survey is a random sample of some 500 high school classes with approximately 12,000 students. In Dutch high schools, classes are primarily composed on the basis of students' academic performance, given school choice.

High school teenagers from a given class are therefore highly homogeneous in terms of cognitive abilities and education level.

All students in a sampled class participate in the survey in principle. Yet, some of them are excluded from the data, for example because a student was absent on the day when the questionnaires were filled out. The survey contains information on time use, income and jobs, expenditures, family background, and on social and psychological aspects of teenage life. There is limited information on parents and on siblings. The seven editions of the NSYS are largely similar, although there have been changes in the wording of some questions (as indicated in the notes to the tables). For the present analysis, all students aged 17 or 18 were selected if they were in a class with at least one other student aged 17 or 18 . Most of these students are in their final high school year. The NSYS shows decreasing sample sizes after 1994 (see table 1, bottom row), and has not been repeated since 2001 .

Due to the combination of its school class based nature, the level of detail on jobs while in school, and the time span covered, the Dutch NSYS is a unique source of information on the earliest stage of individuals' labor market careers.

\section{Gender differences in jobs while in school}

Table 1 reports participation rates, earnings, hours, and wages for all editions of the NSYS. In addition to levels (medians) for boys and for girls, the table reports regressions coefficients on a girl dummy. All these regressions include class-specific fixed effects. A number of other potential controls are practically orthogonal to the girl dummy, and appear to have a negligible effect on the girl dummy outcomes. Since their inclusion would reduce the net sample size due to item specific non-response, they have not been included in the final specification.

During the 17 years considered, the overall participation rate in jobs while in school increased from about 0.5 to 0.6. Except for 1990, the participation differences 
between boys and girls are insignificant. A similar pattern emerges for hours of work. Yet, boys earn about 25 percent more than girls, as shown by the results for earnings and wages. Only for 1999 and 2001 the girl dummies are not significantly different from zero in the earnings and wage regressions. Note, however, that the sample sizes in these years are relatively small. The results are qualitatively in line with those reported in Dustmann et al. (1997) and Pabilonia (2001).

Tables 2 and 3 shed light on the sources of these gender earnings and wage differences. Table 2 reports participation rates for the four most popular job types: working in a store or supermarket, babysitting, delivering newspapers, and working in a restaurant or cafe (participation rates for other job type are generally below 0.05). Boys and girls appear to have very different job type specific participation rates. The participation difference is largest for babysitting - about 85 percent of all babysitting is done by girls. The corresponding girl dummies are significant, large and stable.

The job type specific wages in table 3 reveal two empirical patterns of interest. First, the gender wage differences within job types are insignificant, although most of the girl dummy coefficients have negative signs. Second, there are large wage differences between job types. In all years for which job type specific wages could be computed, the ranking from low to high pay is: babysitting, store/supermarket, restaurant/cafe, and newspaper delivery, for boys as well as for girls. Moreover, between 1994 and 1999 the relative wage of babysitting decreased compared to other job types.

The insignificance of gender differences in observed wages within job types does obviously not preclude significant gender differences in the underlying distributions of potential wages. For example, in the case of newspaper delivery - which is typically done using a bicycle and pays per copy delivered - there may be a gender gap in the distributions of potential wages related to gender differences in speed and physical strength. ${ }^{2}$ The gender patterns in labor market outcomes might therefore partly result from different comparative advantages of boys and girls. In addition, gender differences in preferences are likely to play a role, in supply as well as demand. Preferences may in

\footnotetext{
${ }^{2}$ Moreover, the wages of boys and girls within job types may refer to different types of activities. For example, in supermarkets boys are more involved in loading and unloading and less in cashiering than girls.
} 
turn be affected by (perceived) on-the-job risks. For example, babysitting is generally considered to be a safer type of job than delivering newspapers, especially for girls.

The question arises whether the gender patterns vary with the academic level of a school class. Table 4 reports participation rates in babysitting for classes in VWO, the highest academic level. ${ }^{3}$ The results for this subsample are similar to those in reported in table 2 .

\section{Conclusion}

Boys and girls with almost identical backgrounds appear to accumulate different human capital already in the earliest stage of their labor market careers. As a number of studies have found sizeable and persistent effects of work while in high school on future employment, most of the existing labor market and gender policies seem to miss a potentially important source of labor market gender differences ${ }^{4}$. Effective policies should recognize that gender gaps in the labor market have roots early in life.

\footnotetext{
${ }^{3}$ Within the Dutch educational system four academic levels are distinguished within secondary education. Access to university requires graduation in the highest level (VWO).

${ }^{4}$ Ruhm (1997), for example, finds that jobs held during the senior year of high school are associated with higher future earnings, wages, and occupational status. Hotz (2002) et al. question whether the correlations found in this literature represent causal effects.
} 


\section{References}

Bayard, Kimberly, Judith Hellerstein, David Neumark, and Kenneth Troske (2003), "New Evidence on Sex Segregation and Sex Differences in Wages from Matched Employee-Employer Data", Journal of Labor Economics, vol. 21, pp. 887-922.

Blau, Francine D. and Lawrence M. Kahn (2000), “Gender Differences in Pay”, Journal of Economic Perspectives, vol. 14, pp.75-100.

Blau, Francine D. and Lawrence M. Kahn (2003), "Understanding International Differences in the Gender Pay Gap", Journal of Labor Economics, vol. 21 (Fall), pp.106-144.

Blau, Francine D. and Lawrence M. Kahn (2004), The US Gender Pay Gap in the 1990s: Slowing Convergence, NBER Working Paper \# 10853.

Dustmann, Christian, Najma Rajah, and Stephen Smith (1997), "Teenage Truancy, PartTime Working and Wages”, Journal of Population Economics, vol. 10, pp. 425442.

Hotz, V. Joseph, Lixin Colin Xu, Marta Tienda, and Avner Ahituv (2002), "Are There Returns to the Wages of Young Men from Working While in School?", Review of Economics and Statistics, vol. 84, pp. 221-236.

Pabilonia, Sabrina Wulff (2001), "Evidence on Youth Employment, Earnings, and Parental Transfers in the National Longitudinal Survey of Youths 1997", Journal of Human Resources, vol. 36, pp. 795-822.

Ruhm, Crisptoher (1997), "Is High School Employment Consumption or Investment?", Journal of Labor Economics, vol. 14, pp. 735-776. 


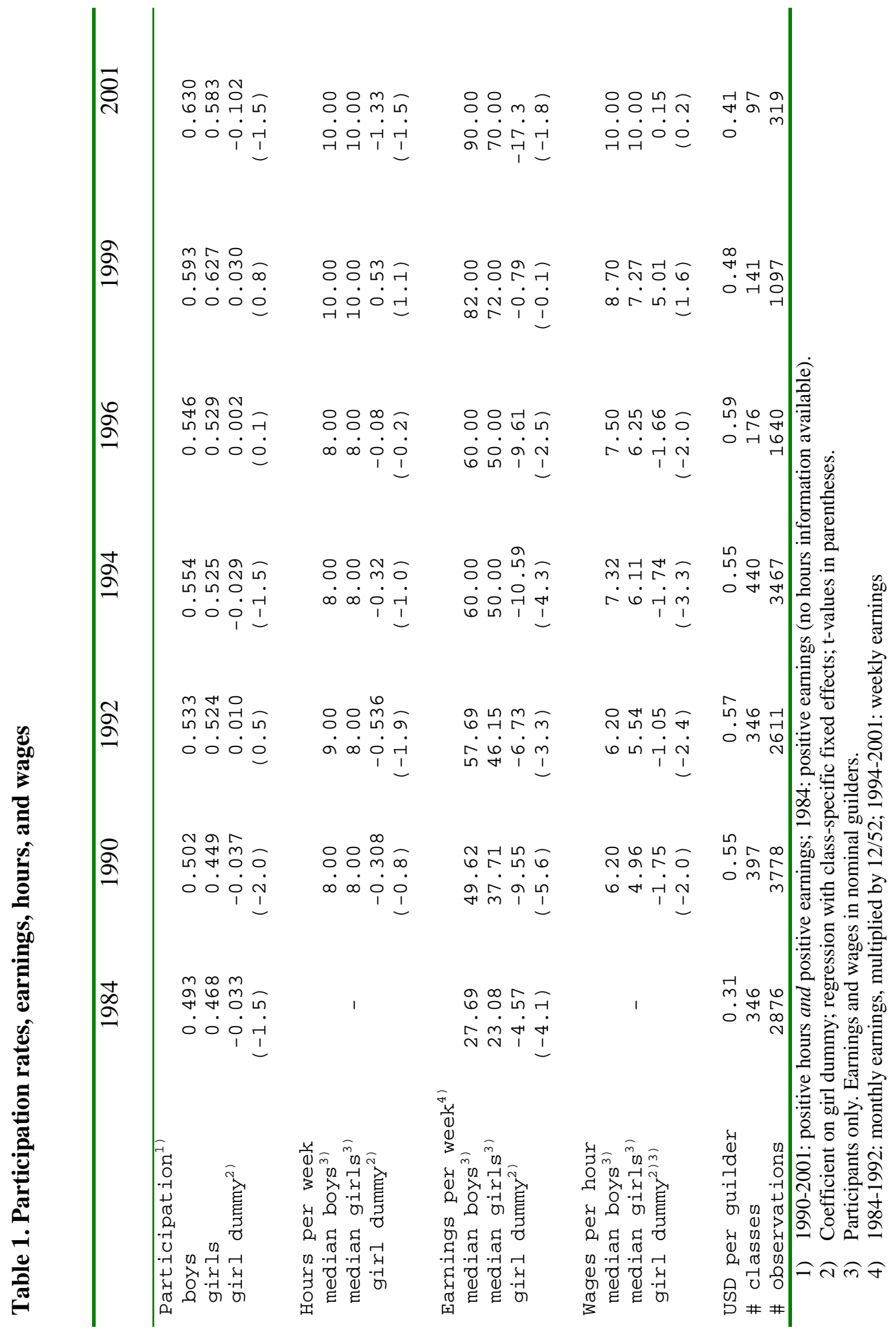




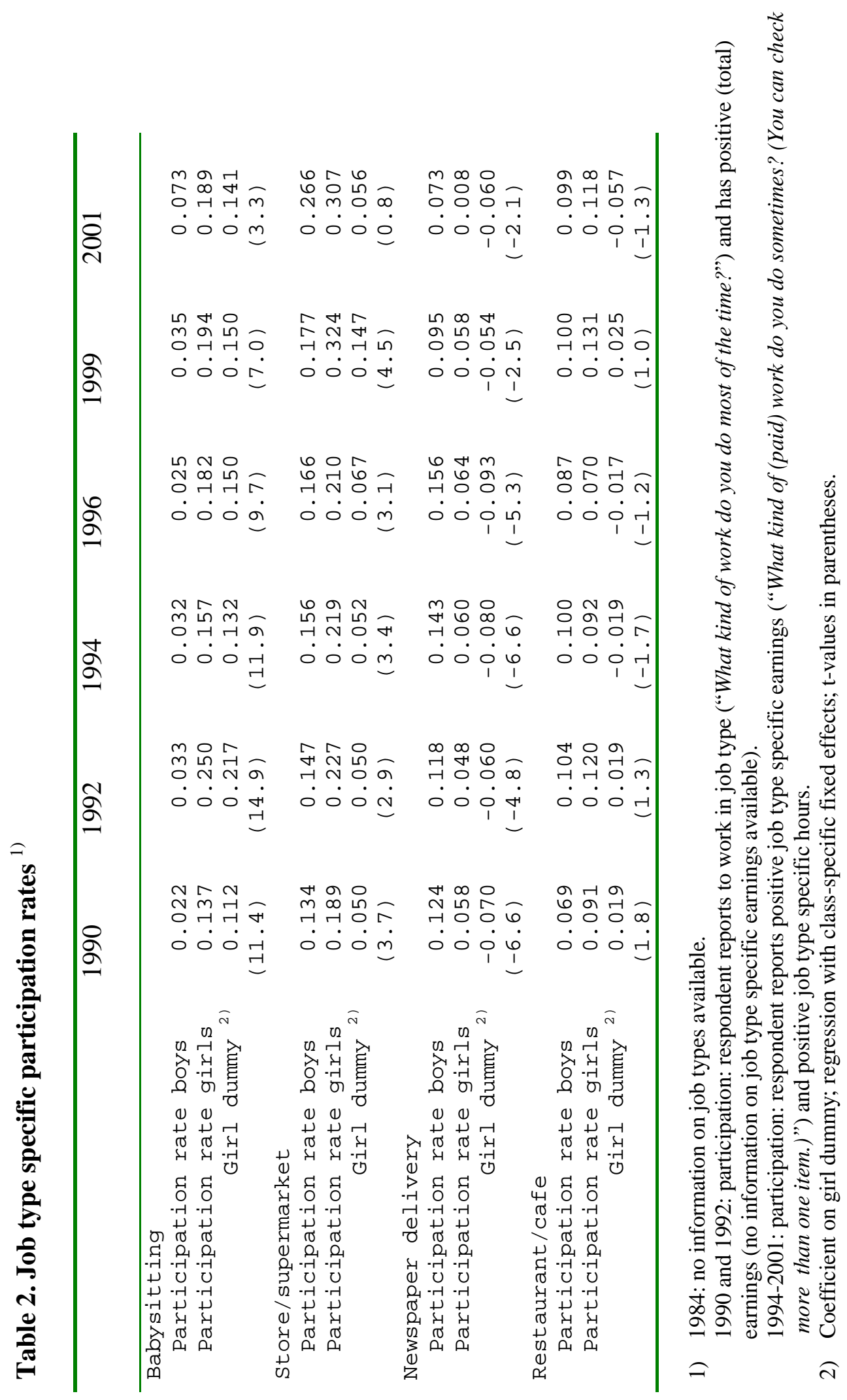




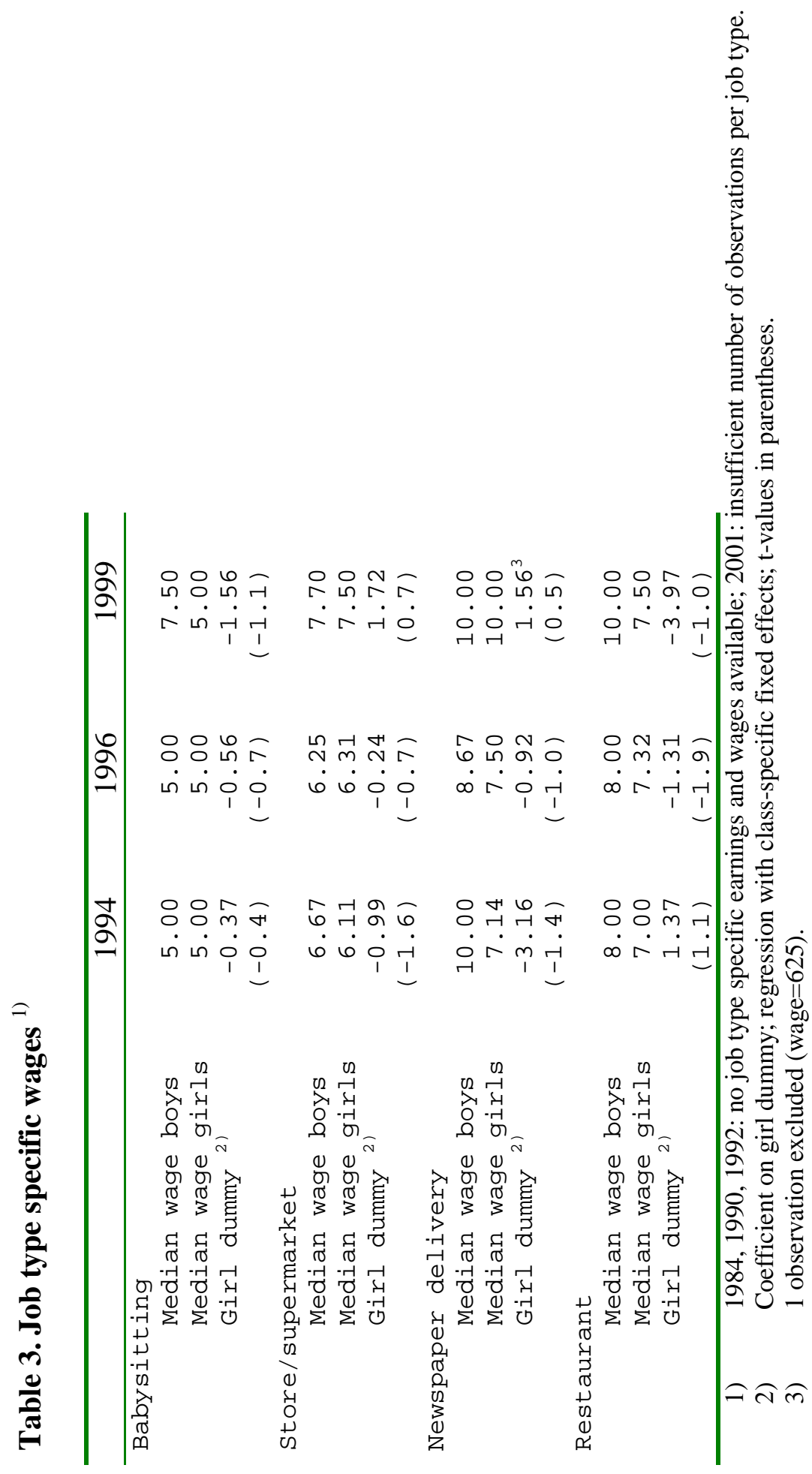




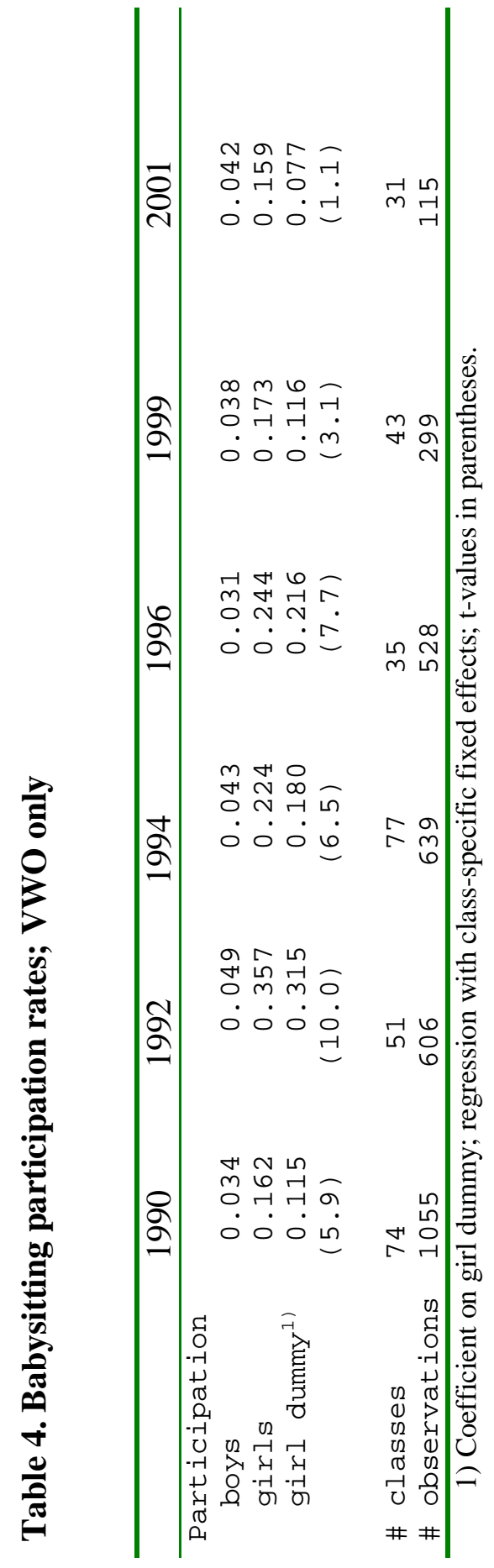

